Зюзя О. В. ${ }^{1}$

Храпач Г. С. ${ }^{2}$
(ORCID: 0000-0002-5248-9579);

(ORCID: 0000-0002-1089-1535)

1 - Національна академія державного управління при Президентові України, Київ;

2 - Центр воєнно-стратегічних досліджень Національного університету оборони України імені Івана Черняховського, Київ

\title{
Дослідження російських геостратегічних цілей стосовно України через призму структурного аналізу збройного конфлікту на Донбасі
}

Резюме. Розкрито результати структурного аналізу збройного конфлікту на Сході України. Визначено механізми управління конфліктністю, які російська сторона застосовує проти України. Проаналізовано та узагальнено вітчизняну і іноземну науково-експертну думку щодо окремих заходів, зокрема, план врегулювання збройного конфлікту на Сході України (поміж іншого, що передбачено “Мінськими угодами”).

Ключові слова: державна безпека; воєнна безпека; загрози; збройний конфлікт; державний суверенітет; територіальна цілісність; геостратегія; геостратегічні та воєнно-політичні цілі; інтереси.

Постановка проблем. Стратегічно важливим завданням національної політики України в умовах зовнішньої агресії Російської Федерації $є$ захист державного суверенітету, відновлення територіальної цілісності України та демократичних інститутів влади на всій ii території, реінтеграція тимчасово окупованих територій після їх звільнення. Такий пріоритет визначено у Стратегії національної безпеки України від 26 травня 2015 року [16].

Аналіз останніх досліджень i публікацій. Розглянуто окремі аналітичні роботи із заданої проблеми російських провідних науковців і експертів, які входять до Наукової ради при Раді безпеки РФ [2, 5, 7, $8,9,13,21]$. У цьому контексті науковоекспертний дискурс Росії вважає, що різка зміна стратегічного курсу розвитку України на західноєвропейський i розгортання російсько-українського конфлікту стало причиною виникнення таких загроз національній безпеці РФ:

y геополітичній сфері - порушення Євроатлантичним співтовариством принципу рівноваги сил, рівної і неподільної безпеки у Європі; принципова зміна регіонального балансу сил на користь “Заходу" в районах, які мають ключове значення у системі міжнародних відносин;

у воєнно-політичній сфері - розширення блоку НАТО на “Схід”, що надає останньому значні переваги у реалізації концепції “миттєвого удару” стосовно РФ; послаблення російської геостратегічної оборони через втрати контролю над Україною, як “буферною зоною” у континентальному поясі безпеки Російської Федерації.
Досліджено наукову думку із зазначеної проблематики вітчизняних науковців i експертів $[1,3,4,8,6,10-12,14,15,17-19,20$, 22, 23-26, 27]. Українські вчені стверджують, що російська сторона активно розробляє нові форми ведення війни, передусім, 3 використанням новітнього озброєння i технологій у комбінації із застосуванням невійськових засобів.

Отже, маємо констатувати, що проблема сучасної українсько-російської міждержавної конфліктності $є$ доволі актуальною темою досліджень у науковому i експертному середовищі. Водночас вбачається, що на сьогодні залишається обмаль наукових i експертно-аналітичних праць щодо проведення структурного аналізу збройного конфлікту на Донбасі, а також розроблення ефективних комплексних заходів протидії російській гібридній агресії.

Метою статті $є$ дослідження геостратегічних цілей Російської Федерації стосовно України через призму проведення структурного аналізу збройного конфлікту на Донбасі.

Виклад основного матеріалу. Домінуючими чинниками, що впливають на розвиток українсько-російської кризи $\epsilon$ геополітичні, геоекономічні, геостратегічні, воєнно-політичні, безпекові. До другорядних (похідних від головних) можна віднести політико-ідеологічні, етнічні, гуманітарні, соціальні, інформаційні складові. Провідна роль належить воєнно-політичному, безпековому i геоекономічному факторам. Останній пов'язаний 3 перерозподілом сфер геоекономічного впливу між провідними світовими центрами у боротьбі за ринки збуту, 
ресурси виробництва та контроль над комунікаціями [11, с. 60-67].

Суб’єктів конфлікту доцільно розділити

на чотири умовні групи, залежно від характеру їх прямої чи опосередкованої участі у конфлікті та його врегулюванні.

\section{Структуризація конфліктних груп та їх характеристики}

\begin{tabular}{|c|c|c|}
\hline Група & Суб'скти груп конфлікту & Характеристика \\
\hline Група I & $\begin{array}{l}\text { Вище керівництво Росії } \\
\text { Вище керівництво України }\end{array}$ & $\begin{array}{l}\text { Сторони знаходяться під тиском власних політико-ідеологічних } \\
\text { платформ, ім притаманна абсолютизація національних інтересів. } \\
\text { Влада РФ всебічно підтримує проросійські сепаратистські } \\
\text { воєнізовані формування на Сході України. Вона класифікує } \\
\text { бойовиків “Донецької народної республіки (ДНР) / “Луганської } \\
\text { народної республіки” (ЛНР) як захисників “русского мира” в } \\
\text { Україні і як радикально-налаштованих суб'єктів української } \\
\text { внутрішньополітичної опозиції до діючої влади в Україні. } \\
\text { Керівництво РФ не визнає пряму участь у збройному конфлікті } \\
\text { російських регулярних військ і всебічно намагається } \\
\text { дискредитувати діючу українську владу. } \\
\text { Керівництво України має підтримку з боку держав } \\
\text { Євроатлантичного співтовариства, які здійснюють тиск на РФ } \\
\text { (США, ЄС, НАТО), як на агресора, шляхом запровадження санкцій. } \\
\text { Політична воля вищого керівництва України залежить від } \\
\text { політичної волі урядів держав-стратегічних партнерів (зокрема, } \\
\text { США, Німеччини, Франції, а також керівництва ЄС). Зазначене } \\
\text { пов’язано зі спільним планом дій щодо врегулювання збройного } \\
\text { конфлікту і тиску на РФ та змушенністю української сторони } \\
\text { враховувати національні інтереси союзників }\end{array}$ \\
\hline Група II & $\begin{array}{l}\text { Безпосередні учасники бойових дій у } \\
\text { зоні збройного протистояння: } \\
3 \text { боку України: } \\
\text { командування і в/с ЗС України; } \\
\text { бійці українських добробатів; } \\
3 \text { іншого боку: } \\
\text { бойовики “ДНР” і “ЛНР”, російських } \\
\text { ПВК і т. зв. воєнно-патріотичних } \\
\text { формувань Росії; } \\
\text { сили спецоперацій і і корпус } \\
\text { військових радників ЗС РФ, що } \\
\text { діють під прикриттям }\end{array}$ & $\begin{array}{l}\text { Дії зазначених суб’єктів залежать від політичної волі першої групи } \\
\text { учасників конфлікту. Рівень іх конфліктної свідомості } \\
\text { характеризується ворожістю та емоційним несприйняттям один- } \\
\text { одного, необ'єктивною оцінкою конфліктної дійсності. Через це, } \\
\text { суб’єкти не налаштовані на примирення, але є цілком контрольовані } \\
\text { першою групою }\end{array}$ \\
\hline Група III & 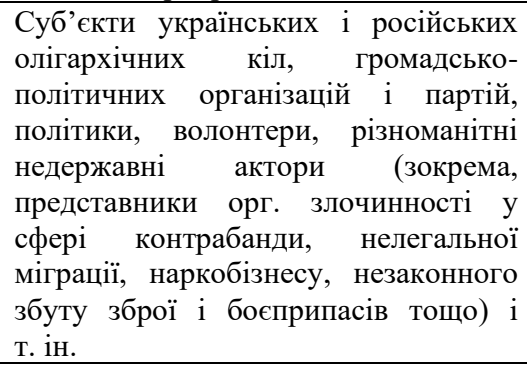 & $\begin{array}{l}\text { Групі характерно відстоювання власних корпоративних інтересів та } \\
\text { реалізації злочинних цілей (останнє у контексті ОЗУ) } \\
\text { використовуючи умови наявного збройного конфлікту. Ці сили } \\
\text { зацікавлені як у його врегулюванні, так і в поглиблені залежно від } \\
\text { досягнення власних цілей. Водночас, сил і засобів впливу для } \\
\text { врегулювання конфлікту у цій групі недостатньо, втім вони здатні } \\
\text { впливати на його ескалацію. Крім того, суб'єктам групи притаманні } \\
\text { бажання вигідно використати ситуацію у корисних цілях, } \\
\text { конкуруюча боротьба, неузгодженість інтересів та інертність у } \\
\text { пошуку консенсусу }\end{array}$ \\
\hline Група IV & $\begin{array}{l}\text { Міжнародні організації ООН, НАТО, } \\
\text { ОБСЄ, ПАСЄ, ОДКБ тощо. } \\
\text { Провідні держави світу та їх } \\
\text { транснаціональні корпорації (ТНК), } \\
\text { які мають інтереси до України } \\
\text { (США, Німеччина, Франція, Велика } \\
\text { Британія, Канада, Італія, Китай } \\
\text { тощо). } \\
\text { Регіональні держави (Польща, } \\
\text { Угорщина, Австрія, Словаччина, } \\
\text { Чехія, Румунія, Білорусь, Молдова, } \\
\text { Грузія, Туреччина, країни Балтії) }\end{array}$ & $\begin{array}{l}\text { Суб'єкти безпосередньо не беруть участь у конфлікті, але } 3 \\
\text { політичних або економічних міркувань підтримують ту чи іншу } \\
\text { сторону та мають на них важелі впливу. Вони відстоюють власні } \\
\text { стратегічні інтереси у “гарячому регіоні", тому не можуть } \\
\text { залишатися сторонніми арбітрами. Крім того, регіональні держави- } \\
\text { сусіди України вкрай зацікавлені у безпековій стабільності у регіоні } \\
\text { для: недопущення його розширення на власну територію (або } \\
\text { морську акваторію), на зони проходження торгівельно-економічних } \\
\text { шляхів; забезпечення безпеки власних кордонів, мінімізації } \\
\text { економічної, політичної, демографічної, екологічної та іншої шкоди } \\
\text { національним і корпоративним інтересам }\end{array}$ \\
\hline
\end{tabular}

Конфліктні дії конфронтуючих сторін на
Донбасі $\quad$ характеризуються збройним протистоянням 3 періодичним проведенням переговорних процесів (у рамках "Мінських угод”) щодо врегулювання конфлікту та

\section{спробами узгодження антагоністичних} політичних суперечностей. Військова сила використовується конфліктуючими сторонами в якості інструменту тиску один на одного для отримання переваги і диктування своїх вимог 
у переговорних процесах. Фактично, наступальна тактика не застосовується обома сторонами. Збройний конфлікт набув рис латентного характеру, його основою не є мета досягнення перемоги над ворогом, а сам процес війни як воєнно-політичний інструмент тиску на супротивника.

Агресивна політика РФ проти нашої держави $є$ своєрідним силовим інструментом тиску Росії на геополітичних опонентів та зриву їх планів щодо європейської інтеграції України, яка реалізується на шкоду національним інтересам РФ. Зі свого боку, “Мінський процес" керівництво РФ розглядає не як майданчик для пошуку шляхів припинення збройного конфлікту, а як "дипломатичну складову" російської “гібридної війни” проти Євроатлантичного співтовариства, що ведеться на території України. Крім того, стратегічною цілю $\epsilon$ здійснення політичного шантажу, насамперед, держав-провідних лідерів Європейського Союзу (Німеччини, Франції) для руйнації західноєвропейської солідарності і єдності, а також поглиблення зовнішньополітичних розбіжностей інтересів зазначених держав 3 США.

На реалізацію цього сценарію істотно впливатиме чинник розвитку відносин у чотирикутнику “США-СС-Росія-Китай” та готовність сторін збалансувати національні інтереси навколо України, визнати іï геополітичну роль у світі, як центру міжцивілізаційного зіткнення “Заходу i Сходу”, який з одного боку має залишатися цілісним, а з іншого - не може стати об'єктом геополітичного контролю однієї зі сторін, оскільки зазначене вкотре призведе до посилення конфліктності у цьому регіоні.

Усі сторони переговорного процесу у рамках "Нормандського формату" збігаються у спільній думці у тому, що виконання комплексу заходів передбачених "Мінськими угодами" у поєднанні 3 проведенням миротворчої місії ООН на Донбасі $\epsilon$ поки єдиним оптимальним шляхом врегулювання збройного конфлікту на Сході України. За результатами узагальнення наукової i експертної думки (зокрема, компетентних представників ОБСЕ, дипломатичного корпусу та науково-експертного середовища Німеччини та Франціi) щодо проблем реалізації "Мінських угод”, вбачається, що органам влади України та іншим сторонам переговорного процесу доцільно зосередити зусилля на розробленні програмно-цільового плану врегулювання збройного конфлікту на Сході України (так званої дорожньої карти) на основі принципів стратегічного планування у сфері національної безпеки $[1,4,11,17,20,23$, $24,27]$. За переконаннями вітчизняних i іноземних експертів, цей план у практичній площині має передбачати (поміж іншого, що передбачено “Мінськими угодами”) реалізацію таких заходів:

Таблиця 2

Узагальнення окремих практичних заходів врегулювання збройного конфлікту на Сході України, що потребують обов'язкового врахування

\begin{tabular}{|c|c|}
\hline $\begin{array}{c}\text { Функції } \\
\text { врегулювання }\end{array}$ & Заходи реалізації \\
\hline $\begin{array}{l}\text { Прогнозна і } \\
\text { програмно- } \\
\text { теоретична }\end{array}$ & $\begin{array}{l}\text { Визначення поточного стану воєнного конфлікту, здійснення прогнозу і розроблення варіантів } \\
\text { його майбутнього розвитку, напрацювання рекомендацій, розроблення паспорту конфлікту, } \\
\text { планування практичних дій щодо урегулювання конфлікту. Зазначене має передбачати: } \\
\text { урахування якомога більшої кількості факторів, їх деталізація і розподіл на окремі підгрупи; } \\
\text { виділення найважливіших факторів; } \\
\text { складання переліку факторів з урахуванням ступеня інтенсивності їх впливу. } \\
\text { дослідження типових збройних конфліктів у минулому та комплексу економічних, політичних, } \\
\text { воєнних, етносоціальних факторів, що зумовили їх появу; } \\
\text { аналіз, пояснення стану збройного конфлікту, складання його базисної теоретичної моделі; } \\
\text { формулювання, на основі якісного прогнозу, можливих варіантів розвитку збройного конфлікту, } \\
\text { очікуваного часу їх здійснення і розрахунку можливих наслідків }\end{array}$ \\
\hline $\begin{array}{c}\text { Правового } \\
\text { забезпечення }\end{array}$ & $\begin{array}{l}\text { Розроблення організаційно-правових механізмів примушення сторін конфлікту до виконання вимог } \\
\text { "Мінських угод”. Зокрема, розроблення механізму спільного розслідування порушень вимог } \\
\text { “Мінських угод” для притягнення до відповідальності винних, а також механізми запобігання } \\
\text { можливим порушенням. Для цього необхідно удосконалити організаційно-правове забезпечення } \\
\text { процесу виконання “Мінських угод” та внести у текст домовленостей правові поправки щодо: } \\
\text { чітких строків проведення визначених заходів врегулювання; } \\
\text { пріоритетності реалізації заходів передбачених “Мінськими угодами”; } \\
\text { конкретизації відповідальності сторін конфлікту (зокрема конкретних осіб) за невиконання заходів, } \\
\text { які передбачені Угодою, що повинно мати форму дієвого покарання. } \\
\text { Правове закріплення на міжнародному рівні (у юридично обов’язковому договорі) досягнення } \\
\text { єдиного “загального політичного рішення” щодо запровадження у Донецькій та Луганській } \\
\text { областях тимчасової міжнародної цивільної адміністрації під керівництвом ООН, передусім, для } \\
\text { гарантування місцевому населенню прав, передбачених “Мінськими угодами”. Відповідний }\end{array}$ \\
\hline
\end{tabular}




\begin{tabular}{|c|c|}
\hline $\begin{array}{c}\text { Функції } \\
\text { врегулювання }\end{array}$ & Заходи реалізації \\
\hline & юридично обов'язковий договір необхідно укласти і ратифікувати на початку перехідного періоду \\
\hline $\begin{array}{c}\text { Організаційно- } \\
\text { підготовча }\end{array}$ & 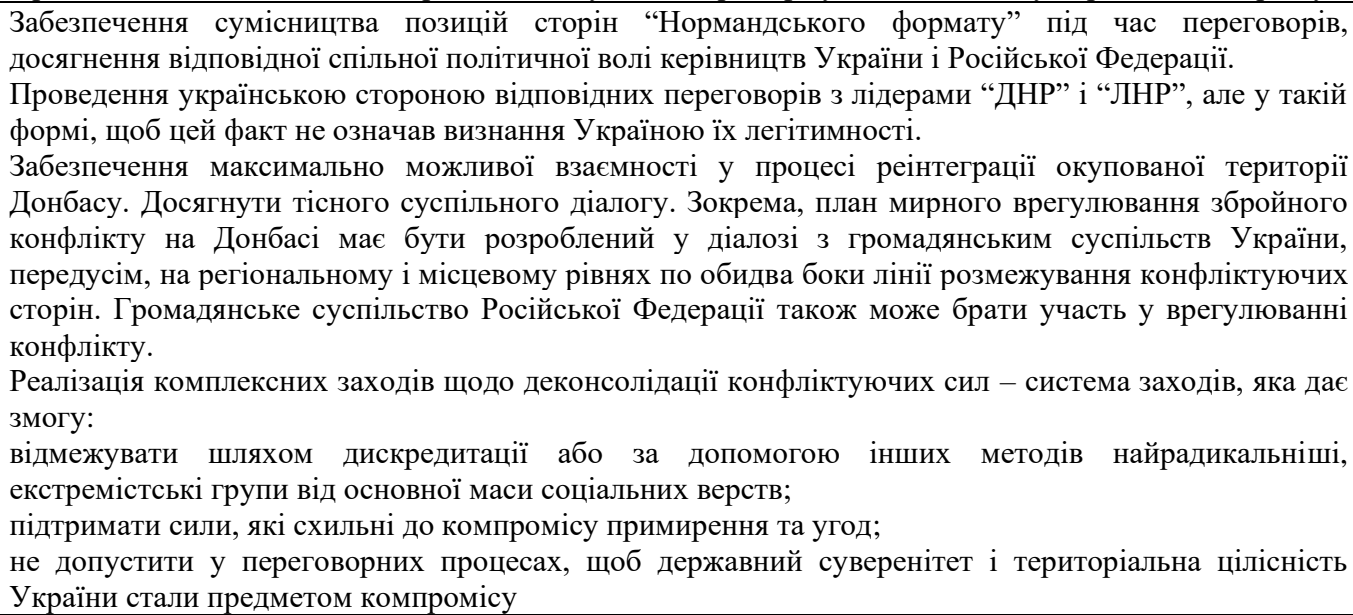 \\
\hline Гуманітарна & $\begin{array}{l}\text { Забезпечення реалізації гуманітарної складової “Мінських угод”. Зокрема, підготовити населення, } \\
\text { яке мешкає на окупованих територій Донбасу, до процесу реінтеграції. Це передбачає: підвищення } \\
\text { рівня довіри людей до влади України, мотивація їх до реінтеграції попри активну антиукраїнську } \\
\text { пропаганду }\end{array}$ \\
\hline $\begin{array}{c}\text { Основоположна- } \\
\text { миротворча }\end{array}$ & 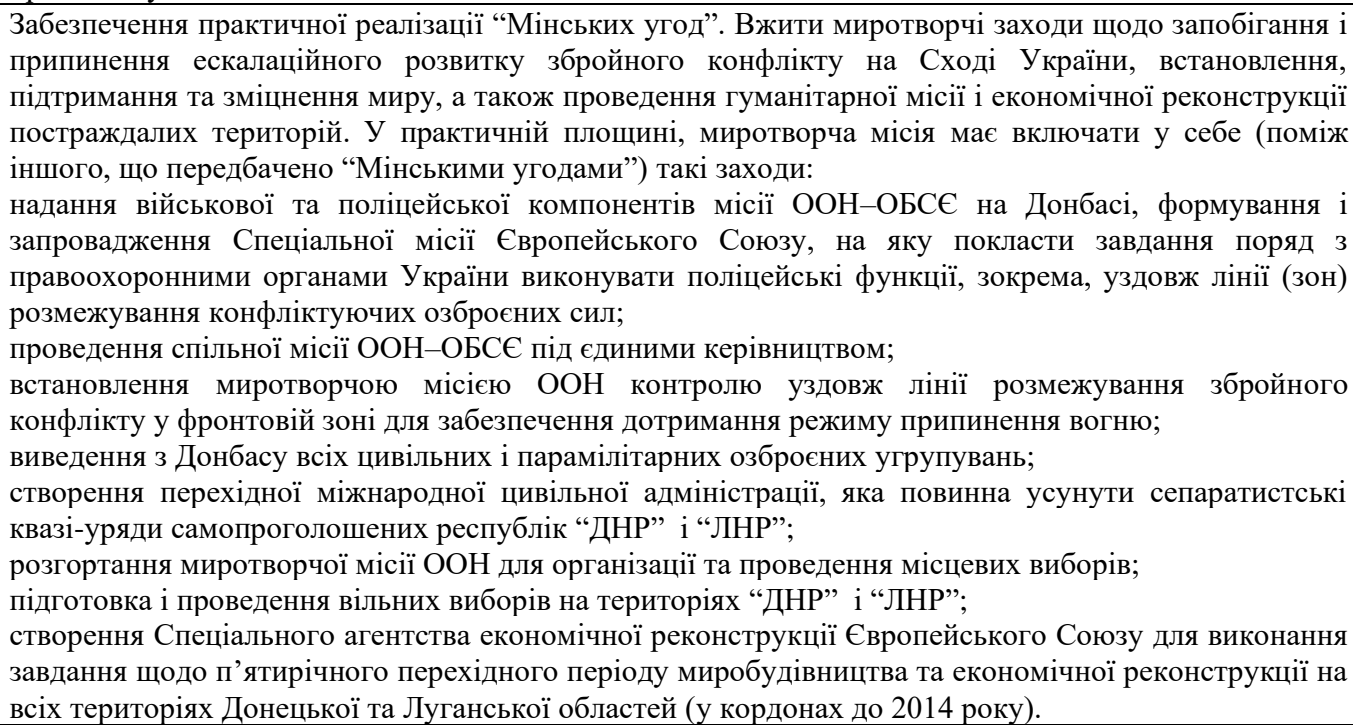 \\
\hline
\end{tabular}

Водночас, із врахуванням аналізу вітчизняних і російських науково-експертних поглядів $[2,3,7,8,9,10,13,14,15,17,21,23$, $26,27]$, особливостей російської стратегічної культури і воєнно-стратегічного мислення [12] та історичного досвіду, вбачається, що керівництво Росії припускає можливість появи фактора синергії у розвитку міжнародних відносин на користь геостратегічних інтересів РФ. Зі свого боку, зазначене може призвести до непередбачуваного розвитку ситуації і змін навколо проблеми врегулювання збройного конфлікту на Сході України.

Висновки. Агресивність російських геостратегічний цілей стосовно України пов'язана передусім 3 геополітичним суперництвом Російської Федерації з США, Європейським Союзом та провідними державами ЄC (зокрема, Німеччиною, Францією, Великою Британією), а також 3 воєнно-політичним протистоянням з НАТО.
За поглядами російської сторони, зовнішній геостратегічний протекторат над Україною забезпечує суттєві переваги щодо геополітичного домінування у Європі та контроль за важливим геоекономічним простором і комунікаціями. 3 позиції воєнної безпеки РФ, українська територія, передусім, розглядається як геостратегічна "буферна зона”, що є невід'ємною складовою територіальної оборони Росії. Сучасні російські геостратегічні цілі відносно України перетинаються 3 асиметричними геостратегічними цілями США та $\mathrm{CC}$, що характеризується певним рівнем антагоністичності та геополітичного напруження. Російська зовнішня політика у даному напрямі зорієнтована на повернення втрачених геостратегічних позицій в Україні, 3 одночасним пошуком компромісних рішень 3 Євроатлантичними суперниками. 3 цією метою, вирішується, насамперед, наявні 
глобальні геополітичні суперечності на рівні чотирихкутника "США - СС - Російська Федерація - КНР”. Особливо важливим для Росії $\epsilon$ врегулювання неузгодженостей національних інтересів і цілей та досягнення компромісу (поступки в обмін на поступки) на рівні: "СС - РФ" і “США - РФ", а також у "Нормандському форматі" (Росія - Німеччина, Франція). До того ж, Україна не розглядається російською стороною як самостійний геополітичний і воєнно-політичний актор. На думку наукового і експертного середовища РФ, зниження градусу напруження між зазначеними геополітичними центрами сили сприятиме врегулюванню конфліктних ситуацій навколо України. Водночас, у разі недосягнення компромісу в українському питанні, уряд РФ, 3 відповідною долею вірогідності, може вдатися до розгортання сценарію "реваншу", зокрема зорієнтованого на регіональну дезінтеграцію України.

В умовах послаблення євроатлантичної солідарності та західноєвропейської єдності, для України зростає рівень ризиків зостатися на самоті з російською агресією та реальними небезпеками для суверенітету Української держави. Отже удосконалення існуючих та напрацювання нових методів i форм виявлення i протидії зовнішнім загрозам національним інтересам України, підготовка ефективних механізмів захисту від геостратегічної експансії вагоміших акторів має стати пріоритетом і головним завданням діяльності усіх суб'єктів забезпечення національної безпеки Української держави.

\section{СПИСОК ВИКОРИСТАНОЇ ЛІТЕРАТУРИ}

1. Про внутрішнє та зовнішнє становище України в 2018 році : Аналітична доповідь до Щорічного Послання Президента України до Верховної Ради України. К. : НІСД, 2018. $281 \mathrm{c.}$

2. Арзуманян Р. В. Стратегия иррегулярной войны: теория и практика применения. URL: http://csef.ru/ru/oborona-i-bezopasnost/504/arzumanyanrv-strategiya-irregulyarnoj-vojny-teoriya-i-praktikaprimeneniya-60941 (дата звернення: 16.09.2019).

3. Горбулин В. П. На вулкане. Ел.видання "Аргумент" (19.06.2018) URL: http://argumentua.com/stati/vladimirgorbulin-na-vulkane (дата звернення - 16.09.2019).

4. Донбас і Крим: ціна повернення / Ред. кол.: В. П. Горбулін (гол. ред.), О. С. Власюк, Е. М. Лібанова, О. М. Ляшенко. К. : НІСД, 2015. 474 с.

5. Карякин В. В. Военно-политические стратегии США и угрозы России : Аналит. обзоры РИСИ / под ред. И. А. Романова. М. : РИСИ, 2014. Вып. 2. 32 с.

6. Кобко Є. В. Моніторинг загроз національній безпеці держави: зарубіжний досвід та українські реалії публічно-правового забезпечення (2018) URL: http://elar.naiau.kiev.ua/jspui/handle/123456789/489 (дата звернення: 16.09.2019).
7. Комлева Н. А. Украинский кризис как элемент “тактики анаконды” (2014). URL: http://www.spacetime.ru/assets/files/2-16.2014/2226-7271 provr-st216.2014.13-komleva.pdf (дата звернення: 16.09.2019).

8. Комлева Н. А. Структура мирового господства : информационный ресурс "Мир прогнозов". URL: http://www.mirprognozov.ru/prognosis/politics/komlevana-struktura-mirovogo-gospodstva/ (дата звернення: 16.09.2019)

9. Круглый стол "Военные концепции и будущее войны”. 26.04.2011 года. Институт международных исследований МГИМО. URL: http://mgimo.ru/about/news/main/186181/1 (дата звернення: 16.09.2019).

10. Лепіхов А. В. Причини та характер сучасних міжнародних конфліктів. Досвід застосування збройних сил у війнах і воєнних конфліктах $\mathrm{XX}$ початку XXI ст.: тенденції та закономірності. 36. наук.прачь. Кол. авторів. За ред. С. В. Сидорова. ЦП “Компринт". 2016. Вип. 5. С. 157-163.

11. Лепіхов А. В. Стан та шляхи вдосконалення державної політики України щодо забезпечення політичної безпеки [Текст] : магістер. робота : заоч. форма навчання. Київ : НАДУ, 2016. URL: http://lib.academy.gov.u (дата звернення: 16.09.2019).

12. Лепіхов. А. В., Храпач Г. С. Російське воєнностратегічне мислення через призму національної стратегічної культури. 3б. наук. пращь ЦВСД НУОУ ім. I. Черняховського. 2018. Вип. № 2 (63). С. 124-128.

13. Політбюро 2.0. и антиистеблишментная волна. Ком. холд. Мінченко консалтинг. м. Москва. Росія (05.06.2019). URL: http://minchenko.ru/netcat_files/userfiles/ PB 2.0 I ANTIISTEBLIShMENTNAYa VOLNA 04.06.19 LAST.pdf (дата звернення: 16.09.2019)

14. Політична криза в Молдові (17.06.2019). URL: http://bintel.com.ua/uk/article/perevorot_moldova/ (дата звернення: 16.09.2019).

15. Почепцов Г. Г. Из истории понятия гибридной войны в США и России. Эллектронное издание Академия, 2015. URL : http://www.academia.edu/17801641/ Из истории понятия гибридной войны в США и России (дата звернення: 16.09.2019).

16. Про рішення Ради національної безпеки і оборони України від 26.05.2015 р. № 287/2015 “Про Стратегію національної безпеки України" URL: https://zakon.rada.gov.ua/laws/show/287/2015 (дата звернення: 23.05.2019).

17. Світова гібридна війна: український фронт / За заг. ред. В. П. Горбуліна. К.: НІСД, 2017. 496 с.

18. Ситник Г. П. Вплив глобалізації на воєнну сферу та принципові особливості сучасних воєнних конфліктів. Академія національної безпеки. URL: http://nationalsecurity.org.ua/2016/07/06/vplivglobalizaciï-na-voehnnu-sferu-ta-principovi-osoblivostisuchasnikh-voehnnikh-konfliktiv/ (дата звернення: 16.09.2019).

19. Смолянюк В. Ф. Системні засади національної безпеки України. Вісник Начіонального юридичного університету ім. Ярослава Мудрого. Харків, 2018. т. 2. Вип. № 37. URL: $\quad$ http://fil.nlu.edu.ua/article/ view/133543.

20. Уткін Е. Конфліктологія: теорія і практика. Асоціація авторів та видавників “Тандем”. М. : Екмос, 1998. 264 c.

21. Фомин А. Н. Прогнозная оценка военнополитической обстановки и сценарии развития России в условиях прогнозируемых действий геополитических и региональных центров сил.Центр стратегических оценок и прогнозов. Оборона и безопасность
URL: 
http://csef.ru/ru/oborona-i-bezopasnost/340/prognoznayaoczenka-voenno-politicheskoj-obstanovki-i-sczenariirazvitiya-rossii-v-usloviyah-prognoziruemyh-dejstvijgeopoliticheskih-i-regionalnyh-czentrov-sil-4081 (дата звернення: 16.09.2019)

22. Цибульський С. І. Особливості геостратегій держав сучасності. Актуальні проблеми міжнародних відносин. 2009. Вип. 84. ч 2. Вид Київський університет IMB. URL: http://www.library.univ.kiev.ua/ukr/elcat/new/detail.php3? doc_id=128892753 (дата звернення: 16.09.2019).

23. Что стоит за указом Путина о выдаче российских паспортов жителям Донбасса (04.05.2019). URL: https://delo.ua/econonomyandpoliticsinukraine/chto-stoitza-ukazom-putina-o-vydache-rossijskih-352775/ (дата звернення: 16.09.2019).

24. Шевченко М. М. Методологічні засади аналізу міждержавного протиборства. Нова парадигма / гол. ред. В.П. Бех. К. : Вид-во НПУ ім. М. Драгоманова, 2007. Вип. 68 . С. $125-133$.

25. Шевченко М. М. Функції та завдання системи забезпечення національної безпеки України в сучасних умовах. Науково-інформаційний вісник Академії національної безпеки. Київ, 2014. Вип. № 3-4. С. 1424. URL: http://nbuv.gov.ua/UJRN/nivanb_2014_3-4_4 (дата звернення: 25.05.2019).

26. Шевченко М. М. Моделі дестабілізації суспільнополітичної i економічної систем на прикладі пострадянських країн. Воєнно-історичний вісник. 2013. № 3. С. 80-87.

27.Яблонський В. М. Україна та проект "русского мира" : Аналітична доповідь Національний інституту стратегічних досліджень при Президентові України. 2014. 80 c. URL: http://www.niss.gov.ua/articles/ 1594/ (дата звернення: 16.09.2019).

Стаття надійшла до редакційної колегії 04.09.2019

Зюзя А. В. ${ }^{1}$;

Храпач A. C. ${ }^{2}$

1 - Национальная академия государственного управления при Президенте Украины, Киев;

2 - Центр военно-стратегических исследований Национального университета обороны Украины имени Ивана Черняховского, Киев

Исследования российских геостратегических целей в отношении Украины через призму структурного анализа вооруженного конфликта на Донбассе

Резюме. Приведены результаты структурного анализа вооруженного конфликта на Востоке Украины. Определены механизмы управления конфликтностью, которые российская сторона применяет против Украины. Проанализированы и обобщены отечественное и иностранное научно-экспертное мнения по отдельным мероприятий, в частности, план урегулирования вооруженного конфликта на востоке Украины.

Ключевые слова: государственная безопасность; военная безопасность; угрозы; вооруженный конфликт; государственный суверенитет; территориальная целостность; геостратегия; геостратегические и военнополитические цели; интересы.

\section{A. Zyuza ${ }^{1}$;}

A. Hrapach ${ }^{2}$

1 - National Academy of Public Administration under the President of Ukraine, Kiev;

${ }^{2}$ - Center for Military and Strategic Studies of the National Defence University of Ukraine named after Ivan Cherniakhovskyi, Kyiv

Studies of Russian geostrategic targets in relation to Ukraine through the prism of a structural analysis of the armed conflict in the Donbass

Resume. The results of the structural analysis of the armed conflict in the east of Ukraine are presented. The conflict management mechanisms that the Russian side applies against Ukraine are determined. The domestic and foreign scientific and expert opinions on individual events, in particular, the plan for resolving the armed conflict in eastern Ukraine, are analyzed and summarized.

Keywords: state security; military security; threats; armed conflict; state sovereignty; territorial integrity; geostrategic; geostrategic and military-political goals; interests. 